\title{
Perlindungan Perempuan dan Pernikahan di Bawah Umur
}

\author{
Dwi Anggun Apriyanti \\ Fakultas Hukum Universitas Bandar Lampung \\ Author's Email Correspondence: dwianggun15@gmail.com
}

\begin{abstract}
ABSTRAK
Advokasi untuk mengakhiri pernikahan anak di Indonesia menghadapi perjuangan berat. Praktik perkawinan anak berakar pada masalah struktural yang lebih luas seperti kemiskinan dan ketimpangan gender yang saling terkait dengan pandangan masyarakat tentang perkawinan, seksualitas, dan moralitas menurut agama dan tradisi. Berkaitan dengan hal tersebut, praktik perkawinan anak harus dipahami dalam berbagai bidang seperti norma agama tentang perkawinan, moralitas seputar seks pranikah, pandangan masyarakat tentang gender serta peran anak dan pola asuh yang tidak semuanya berpihak pada perempuan. Pandangan tentang perkawinan anak, bagaimana perkawinan anak dipraktekkan, peraturan dan penegakannya berbeda-beda dan seringkali kontradiktif antara aktor dan lembaga, namun anak perempuanlah yang paling menderita akibat praktek perkawinan anak. Penelitian ini membahas upaya pemerintah yang telah dilakukan dalam melakukan perlindungan terhadap perempuan dan pernikahan di bawah umur dan melihat sejauh mana tindakan ini dapat meberantas dan melindungi.
\end{abstract}

\section{ARTICLE HISTORY \\ Submission: 2021-02-24 \\ Accepted: 2021-04-22 \\ Publish: 2021-04-26}

KEYWORDS: Protection; wedding; woman.
Kata Kunci: Perempuan; perlindungan; pernikahan.

\begin{abstract}
Advocates for ending child marriage in Indonesia face an uphill battle. The practice of child marriage is rooted in broader structural problems such as poverty and gender inequality which are intertwined with people's views on marriage, sexuality and morality according to religion and tradition. In this regard, the practice of child marriage must be understood in various fields such as religious norms on marriage, morality around premarital sex, people's views on gender and the role of children and parenting, which are not all pro-women. The views on child marriage, how child marriage is practiced, the rules and enforcement are different and often contradictory between actors and institutions, however it is girls who suffer the most as a result of the practice of child marriage. This study discusses the government efforts that have been made in protecting women and underage marriages and sees to what extent these actions can eradicate and protect.
\end{abstract}

\section{A. PENDAHULUAN}

Manusia dalam proses perkembangannya membutuhkan pasangan hidup yang dapat memberikan keturunan untuk meneruskan jenisnya. Perkawinan sebagai jalan yang bisa ditempuh oleh manusia untuk membentuk suatu keluarga atau rumah tangga bahagia yang berdasarkan Ketuhanan Yang Maha Esa. Hal ini dimaksudkan bahwa perkawinan itu dilaksanakan sekali seumur hidup dan tidak berakhir begitu saja. Perkawinan bagi manusia merupakan hal yang penting, karena dengan perkawinan seseorang akan memperoleh keseimbangan hidup baik secara psikologis, sosial, maupun biologis. Seseorang yang melangsungkan perkawinan, maka dengan sendirinya semua kebutuhan biologisnya bisa terpenuhi. kematangan emosi merupakan aspek yang sangat penting untuk menjaga kelangsungan perkawinan. 
Keberhasilan suatu rumah tangga banyak ditentukan oleh kematangan emosi baik suami maupun istri, terutama dalam menghadapi ketika ada perbedaan pendapat antara suami dan istri, jika belum ada kematangan emosi bisa menimbulkan pertengkaran yang terus menerus yang bisa saja akhirnya berujung pada perceraian. Dengan dilangsungkannya suatu perkawinan, maka status sosialnya diakui dalam kehidupan bermasyarakat dan sah secara hukum. Perkawinan pada umumnya dilakukan oleh orang dewasa dengan tidak memandang profesi, suku bangsa, kaya atau miskin, dan sebagainya. Namun tidak sedikit manusia yang sudah mempunyai kemampuan baik dari segi fisik maupun mental akan mencari pasangan hidup sesuai kriteria yang diinginkannya. Dalam kehidupan manusia, perkawinan seharusnya menjadi sesuatu yang bersifat seumur hidup, bukan sementara. Tetapi tidak semua orang bisa memahami hakikat dan tujuan perkawinan yang seutuhnya yaitu mendapatkan kebahagiaan yang sejati dalam kehidupan berumah tangga. Batas usia dalam melaksanakan perkawinan sangatlah penting karena didalam perkawinan menghendaki kematangan psikologis, karena faktor kesiapan dari sisi mental sangat di perlukan dalam menjalani kehidupan berumah tangga, selain kesiapan dari sisi finansial/ekonomi. Usia perkawinan yang terlalu muda dapat mengakibatkan meningkatnya kasus perceraian karena kurangnya kesadaran untuk bertanggung jawab dalam kehidupan berumah tangga, masih mengedepankan ego masing-masing sebelum mereka menikah, sehingga sering terjadinya pertengkaran antara suami istri karena semua bertahan dengan egonya yang merasa paling benar. Perkawinan yang sukses sering ditandai dengan kesiapan memikul tanggung jawab bersama antara suami istri, masing masing baik suami dan istrinya tahu apa yang menjadi kewajiban dan hak dalam sebuat perkawinan.

Pernikahan sebelum usia 18 tahun adalah kenyataan bagi banyak anak terutama perempuan. Di banyak belahan dunia, orang tua mendorong pernikahan anak perempuan saat mereka masih anak-anak dengan harapan pernikahan tersebut akan menguntungkan baik secara finansial maupun sosial, sekaligus meringankan beban keuangan keluarga dan tidak mempertimbangan kesiapan secara psikologis sebagai suami dan istri yang pasti akan mempengaruhi kelangsungan sebuah perkawinan. Pada kenyataannya, pernikahan anak adalah pelanggaran hak asasi manusia, membahayakan perkembangan anak perempuan dan seringkali mengakibatkan kehamilan dini dan isolasi sosial, dengan sedikit pendidikan dan pelatihan kejuruan yang buruk yang memperkuat sifat kemiskinan gender.

Pernikahan anak adalah pelanggaran mendasar hak asasi anak perempuan yang seharusnya tidak terjadi dan tidak dipaksakan oleh orang tua dengan alasan apapun itu. Pembatasan terhadap pendidikan anak, kesehatan, pendapatan masa depan, keamanan, hak pilihan dan kemampuan dan juga membatasi status dan peran mereka baik di rumah maupun di masyarakat. Praktik ini sebagian besar didorong oleh kemiskinan dan norma-norma sosial yang berakar pada status perempuan dan anak perempuan yang lebih rendah. Gadis-gadis yang menikah lebih dini menghadapi risiko yang merugikan bagi kesehatan dan kesejahteraan. Kematian terkait kehamilan adalah salah satu penyebab utama kematian di kalangan gadis berusia 15 hingga 19 tahun di seluruh dunia ${ }^{1}$ dan harusnya itu jadi pertimbangan penting orang tua yang memaksakan kehendaknya untuk menikahkan anaknya yang belum layak secara umur untuk menikah. Perempuan di bawah umur yang sudah menikah lebih mungkin mengalami pelecehan dan kekerasan dalam rumah tangga dan seringkali tidak dapat secara efektif menegosiasikan seks yang lebih aman, oleh karena itu mereka rentan

1 World Health Statistic, Monitoring Health for the SDGs, World Health Statistic, 2019. https://doi.org/10.1007/978-1-349-04787-1_12. 
terhadap infeksi menular seksual, termasuk HIV². Perempuan dibawah umur yang sudah menikah juga memiliki prospek pendidikan dan ekonomi yang lebih buruk, yang memperkuat status yang lebih rendah dan membatasi kemampuan untuk mengangkat diri mereka sendiri dan keluarga dari kemiskinan. Efek ini diteruskan ke anak-anak mereka, berlanjut ke generasi mendatang, dan berfungsi sebagai penguras pertumbuhan sosial dan ekonomi ${ }^{3}$. Bagi perekonomian di Indonesia, pernikahan anak di Indonesia menyebabkan kerugian setidaknya 1,7 persen dari PDB pada tahun 20144 .

Indonesia merupakan salah satu negara dengan persentase pernikahan muda tertinggi di dunia, peringkat ke-37 dunia, sedangkan di tingkat ASEAN, tertinggi kedua setelah Kamboja5. Pengadilan Agama pada tahun 2014 mencatat 11.774 anak Indonesia menikah dini. Salah satu penyebab utamanya terjadi pernikahan di bawah umur adalah adanya kehamilan di luar nikah. Tren pernikahan dini terus meningkat, begitu pula angka perceraian, juga terjadi peningkatan karena adanya ketidak mampuan pasangan suami istri ini dalam mengedalikan diri, melupakan tujuan utama melaksanakan pernikahan itu. Berdasarkan penelitian yang dilakukan oleh Pusat Penelitian dan Pelatihan Rifka Annisa, ditemukan bahwa mereka yang melakukan pernikahan dini rentan terhadap perceraian, dengan berbagai factor penyebabnya. Salah satu faktor utama penyebab terjadinya perkawinan di bawah umur adalah ketidaksiapan calon pengantin yang masih dibawah umur dalam memasuki kehidupan berrumah tangga, selain itu kekerasan dalam Rumah Tangga (KDRT) juga sering menjadi alasan ${ }^{6}$ yang mendasari terjadi perceraian.

Hak atas persetujuan 'bebas dan penuh' untuk sebuah pernikahan diakui dalam Deklarasi Universal Hak Asasi Manusia - dengan pengakuan bahwa persetujuan tidak bisa 'bebas dan penuh' ketika salah satu pihak yang terlibat tidak cukup dewasa untuk membuat keputusan yang tepat tentang pasangan hidup. Konvensi Penghapusan Segala Bentuk Diskriminasi terhadap Perempuan menyebutkan hak atas perlindungan dari perkawinan anak dalam Pasal 16, yang menyatakan: "Pertunangan dan perkawinan anak tidak akan memiliki dampak hukum, dan semua tindakan yang diperlukan, termasuk undang-undang, harus diambil untuk menentukan usia minimum untuk menikah ..." "7 Meskipun pernikahan tidak dipertimbangkan secara langsung dalam Konvensi Hak Anak, pernikahan anak dikaitkan dengan hak lain - seperti hak untuk mengekspresikan pandangan mereka secara bebas, hak atas perlindungan dari segala bentuk pelecehan, dan hak untuk dilindungi dari praktik-praktik tradisional yang berbahaya - dan sering kali ditangani oleh Komite Hak Anak.

\section{B. METODE PENELITIAN}

2 Bushra Sabri et al., Intimate Partner Violence, HIV and Sexually Transmitted Infections in Fishing, Trading and Agrarian Communities in Rakai, Uganda, BMC Public Health, 2019. https://doi.org/10.1186/s12889-019-6909-8.

3 Emy Susanti, Unequal Gender Relations in the Practices of Girl Marriage in Poor Families at East Java Province, Masyarakat, Kebudayaan Dan Politik, 2019. https://doi.org/10.20473/mkp.v31i42018.440-450.

4 Lauren Rumble et al., An Empirical Exploration of Female Child Marriage Determinants in Indonesia, BMC Public Health, 2018. https://doi.org/10.1186/s12889-018-5313-0.

5 Sonny Dewi Judiasih et al., Women, Law and Policy: Child Marriage Practices in Indonesia, NOTARIIL: Jurnal Kenotariatan, 2018. https://doi.org/10.22225/jn.3.1.647.47-55.

6 Kurnia Muhajarah, Kekerasan Terhadap Perempuan Dalam Rumah Tangga: Perspektif SosioBudaya, Hukum, Dan Agama," Sawwa: Jurnal Studi Gender, 2017, https://doi.org/10.21580/sa.v11i2.1452.

7 International Law Making, Dekiarasi Universal Hak-Hak Asasi Manusia, Indonesian Journal of International Law, 2006. https://doi.org/10.1017/CB09781107415324.004. 
Penelitian ini merupakan penelitian normatif (kepustakaan). Penelusuran data tertulis melalui undang-undang dan buku. Teknik pengumpulan data yang digunakan dalam penelitian ini adalah dokumentasi. Sedangkan analisis yang digunakan dalam penelitian ini adalah deskriptif kualitatif. Analisis dilakukan dengan, pertama, pengumpulan data berupa peraturan perundang-undangan yang menjadi objek penelitian; kedua, mereduksi data melalui kategorisasi atau identifikasi awal untuk menentukan topik yang akan digunakan; ketiga, penyajian data yang disajikan secara tertulis atau lisan secara sistematis; dan keempat, menarik kesimpulan.

\section{PEMBAHASAN}

Perkawinan merupakan ikatan sah untuk membina rumah tangga dan keluarga yang sejahtera, bahagia, di mana suami dan istri mengemban amanah dan tanggung jawab yang besar. Istri akan mengalami kehamilan dan persalinan yang penuh pengorbanan. Mengingat beratnya tugas istri, Undang-Undang Perkawinan mensyaratkan usia minimal menikah, yakni 16 tahun untuk perempuan dan 19 tahun untuk laki-laki. Namun kenyataannya di banyak masyarakat terjadi perkawinan di bawah umur (menikah pada usia 14 tahun) karena berbagai alasan seperti alasan ekonomi keluarga, budaya, kehamilan yang tidak diinginkan dan sebagainya.

Advokasi penghapusan perkawinan anak telah dilakukan di tingkat desa, kabupaten hingga nasional oleh berbagai organisasi dan aliansi di seluruh Indonesia, untuk mencegah atau setidaknya mengurangi terjadinya pernikahan di bawah umur. Di tingkat nasional, advokasi dilakukan oleh lembaga donor internasional, LSM, Kementerian Pemberdayaan Perempuan dan Perlindungan Anak, serta Menteri Koordinator Bidang Pembangunan Manusia dan Kebudayaan mendorong Jokowi untuk mengeluarkan Peraturan Pemerintah Pengganti Undang-Undang (Perppu). Jokowi berjanji akan mengeluarkan keputusan untuk melarang pernikahan anak pada April 2018 namun hingga akhir 2018, janji tersebut belum terpenuhi. Perubahan undang undang pun ditetapkan yaitu UU No. 16/20198 tentang Perubahan atas UU No. 1/19749 tentang Perkawinan telah menaikkan usia minimal kawin perempuan dari 16 tahun menjadi 19 tahun. Dengan demikian, usia kawin perempuan dan laki-laki sama-sama 19 tahun. Yang dimaksud dengan perkawinan di bawah umur adalah perkawinan atau akad yang dapat menjamin seorang laki-laki dan seorang perempuan memiliki hubungan yang saling menguntungkan dan dapat melakukan hubungan perkawinan, dan perkawinan tersebut dilakukan oleh seseorang (calon suami / calon istri) yang ditentukan oleh undang-undang. yang berlaku di Indonesia yang telah ditetapkan oleh pemerintah.

Selain itu, dampak perkawinan dini memicu kualitas rumah tangga pada kinerja yang kurang baik dalam kesehatan reproduksi, kesiapan psikologis dan ekonomi keluarga sehingga rentan terkena dampak perceraian dan kualitas pendidikan yang terabaikan bagi anak. Lebih dari itu, hal tersebut berdampak pada kurangnya kematangan psikologis, kurang pertimbangan dalam menyelesaikan masalah, kurang optimal dalam mengerjakan tugas-tugasnya. Lebih jauh, emosi mereka belum stabil dalam menyelesaikan permasalahan yang terjadi dalam rumah tangga, sehingga keputusan yang di ambil untuk menyelesaikan masalah tersebut juga tidak di pertimbangkan dengan matang hanya mengikuti emosional saja.

Menjadi kewajiban orang tua untuk melindungi, mendidik, bahkan menghidupi anaknya sampai melangkah menuju kedewasaan. Anak harus dilindungi dari hal-hal yang berdampak negatif pada perkembangannya, baik secara fisik maupun psikis.

\footnotetext{
8 Republik Indonesia, “UNDANG-UNDANG REPUBLIK INDONESIA NOMOR 16 TAHUN 2019,"

${ }^{9}$ Republik Indonesia, “UNDANG-UNDANG REPUBLIK INDONESIA No. 1 Tahun 1974,”.
} 
Terjadinya pernikahan di bawah umur menjadikan perlindungan orang tua berkurang dengan beralihnya ke suami. Anak harus dilindungi dari pernikahan dini yang berdampak pada perkembangan dirinya, baik fisik maupun psikis.

Undang-Undang Nomor 35 Tahun 2014 tentang Perlindungan Anak telah memuat ancaman pidana bagi pelanggar. Dalam kasus perkawinan di bawah umur, dalam pasal 82 Undang-Undang Nomor 35 Tahun 2014 disebutkan bahwa barang siapa yang melakukan rayuan, penipuan, serangkaian kebohongan, atau membujuk anak untuk melakukan atau membiarkan perbuatan cabul, maka makan dipidana dengan pidana penjara paling lama 3 orang ( tiga) sampai dengan 15 (lima belas) tahun dan denda paling banyak Rp. 300.000.000 (tiga ratus juta rupiah) dan paling sedikit Rp. 60.000.000 (enam puluh juta rupiah). Dengan demikian, Undang-Undang Nomor 35 Tahun 2014 tentang Perlindungan Anak cukup ketat dalam memberikan sanksi kepada pelanggarnya.

Selama sembilan tahun terakhir, dinamika pernikahan anak mengalami fluktuasi.hingga 2017 persentasenya meningkat tajam hingga mencapai 25,7 persen, kondisi ini sangat mengkhawatirkan jika terus terjadi dan belum bisa di cegah padahal Hal ini menjadi masalah yang serius karena telah menimbulkan kontroversi di masyarakat, tidak hanya di Indonesia tetapi telah menjadi isu internasional ${ }^{10}$.

Dibawah ini terdapat beberapa faktor yang memperkuat terjadinya pernikahan anak dibawah umur:

\section{Taraf Pendidikan}

Di Indonesia, perkawinan anak juga diperparah oleh ada anggapan umum bahwa anak perempuan tidak perlu melanjutkan pendidikan tinggi karena pada akhirnya mereka akan menjadi ibu rumah tangga. Angka pernikahan anak lebih rendah untuk anak perempuan yang yang telah menyelesaikan pendidikan menengah atas atau lebih tinggi yang dibuktikan dalam sebuah studi tahun 2020 menunjukkan bahwa menyelesaikan sekolah menengah dapat melindungi anak perempuan untuk menikah sejak dini di Indonesia11.

Penelitian yang dilakukan oleh organisasi MAMPU bekerja sama dengan Kementrian PPN/Bappenas pada tahun 2020 menghasilkan kesimpulan berupa pernikahan anak dan pendidikan terkait erat karena anak-anak berhenti bersekolah ketika mereka menikah. Membuat program dimana membantu dan mengurangi biaya pendidikan orang tua berpotensi menunda usia pernikahan karena orang tua mungkin lebih cenderung menyekolahkan anak perempuan (dan anak laki-laki) daripada menikahi mereka, kalo ini bisa di laksanakan maka bisa mencegah terjadinya perkawinan di bawah umur. Hal ini dapat dilakukan dengan meningkatkan kemampuan keluarga terhadap akses pendidikan, baik secara fisik melalui pembangunan sekolah dan / atau dengan mengurangi biaya pendidikan. Pendidikan formal yang digabungkan dengan program pendidikan lain seperti pelatihan kejuruan juga berpotensi memberdayakan kaum muda untuk membuat keputusan yang lebih tepat atas masa depan mereka. Program yang mendidik wanita muda tentang seks,

10 Sri Murni, The Marriage Age Limit According to Indonesian Law No. 16, 2019 as Effort to Child Protection 140, No. 16 (2020): 222-30.

https://doi.org/10.2991/aebmr.k.200513.047.

11 Ayako Kohno et al., Investigation of the Key Factors That Influence the Girls to Enter into Child Marriage: A Meta-Synthesis of Qualitative Evidence, PLoS ONE, 2020. https://doi.org/10.1371/journal.pone.0235959. 
reproduksi, dan pernikahan juga terbukti dapat menunda pernikahan dan kehamilan ${ }^{12}$.

Dikatakan bahwa pendidikan adalah prediktor positif yang kuat dari usia perempuan saat menikah ${ }^{13}$. Anak perempuan yang tidak berpendidikan tiga kali lebih mungkin untuk menikah atau menikah sebelum usia 18 tahun dibandingkan dengan mereka yang berpendidikan menengah atau lebih tinggi ${ }^{14}$. Sekolah menengah mewajibkan anak perempuan untuk tidak menikah di Indonesia,. Namun, begitu mereka tidak lagi bersekolah, anak perempuan lebih cenderung dipandang layak untuk dinikahi ${ }^{15}$, yang mengarah pada kerentanan yang meningkat terhadap pernikahan dini. Selanjutnya, anak perempuan yang sudah menikah secara drastis lebih kecil kemungkinannya untuk bersekolah dibandingkan teman-teman mereka yang belum menikah.

\section{Faktor Ekonomi}

Anak perempuan yang tinggal di keluarga dengan tingkat penghasilan yang rendah dan kondisi yang tidak memadai lebih mungkin untuk menikah lebih awal, adanya keadaan dalam keluarga yang memaksa anak menerima keputusan orang tuanya untuk menikahkannya padahal bukan kemauan si anak. Keluarga menikahkan anak perempuan sebagai cara untuk mengurangi beban ekonomi keluarga.

Studi yang dilakukan oleh Paul pada tahun 2019 meneliti pengaruh pencapaian pendidikan anak perempuan dan kemiskinan rumah tangga terhadap prevalensi perkawinan anak di tingkat kabupaten di India. Pada penelitian ini didapatkan bahwa tingkat pendidikan menengah dan tinggi yang lebih tinggi secara signifikan mengurangi prevalensi perkawinan anak perempuan. Hasilnya menunjukkan bahwa peningkatan kesempatan untuk pendidikan anak perempuan dan dukungan keuangan bagi keluarga miskin dapat menjadi strategi efektif untuk menghapus praktik pernikahan anak perempuan di India ${ }^{16}$.

\section{Kehormatan keluarga}

Penelitian telah menunjukkan bahwa perkawinan terkadang digunakan sebagai cara untuk mencegah atau memperbaiki stigma yang terkait dengan pengalaman seksual perempuan di luar nikah dan kehamilan remaja, termasuk melalui kekerasan seksual. Dalam hal ini, disadari atau tidak, banyak korban dihadapkan dengan keadaan dimana mereka tidak dapat menjalani hidup sebagaimana mestinya karena telah menjadi korban kekerasan seksual, karena sentimen aib, atau membuat malu keluarga yang membuat mereka dijauhi oleh masyarakat.

12 MAMPU, Consequences of Child Marriage in Indonesia, 2020.

13 Peter Glick, Christopher Handy, and David E. Sahn, Schooling, Marriage, and Age at First Birth in Madagascar, Population Studies, 2015.

https://doi.org/10.1080/00324728.2015.1053513.

14 Jennifer McCleary-Sills et al., Child Marriage: A Critical Barrier to Girls' Schooling and Gender Equality in Education, Review of Faith and International Affairs, 2015. https://doi.org/10.1080/15570274.2015.1075755.

15 Susan Lee-Rife et al., What Works to Prevent Child Marriage: A Review of the Evidence," Studies in Family Planning, 2012.

https://doi.org/10.1111/j.1728-4465.2012.00327.x.

16 Pintu Paul, Effects of Education and Poverty on the Prevalence of Girl Child Marriage in India: A District-Level Analysis, Children and Youth Services Review, 2019. https://doi.org/10.1016/j.childyouth.2019.02.033. 
Pada Penelitian yang dilakukan oleh United Nations Population Fund di Palu, Sigi Donggala Sulawesi Tengah di mana para pelaku kejahatan seksual, jika tertangkap, akan dikenakan beberapa hukuman adat. Instrumen adat adalah cara yang umum untuk menangani masalah kekerasan berbasis gender di mana pelakuny jika tertangkap akan diadili oleh kepala adat untuk mendapatkan hukuman disiplin dan harus membayar denda kepada keluarga korban, serta harus menikahi korban, atau keduanya: membayar denda dan menikah. Hal ini adalah beberapa alasan mengapa pernikahan anak dibawah umur terjadi dan banyak korban tidak melaporkan kekerasan seksual yang mereka alami kepada pihak berwajib, keluarga dan maupun komunitasnya ${ }^{17}$.

\section{Norma Gender}

Norma sosial yang menerima perkawinan anak berpengaruh di semua tingkat sosial ekonomi masyarakat Indonesia. Pada 2015, hampir satu dari delapan anak perempuan yang menikah sebelum usia 18 tahun berasal dari rumah tangga dengan tingkat penghasilan rendah. Sebuah studi tahun 2019 mengungkapkan bahwa pernikahan anak lebih menurun di antara kelompok yang kurang beruntung daripada kelompok yang lebih kaya. Ini menunjukkan bahwa keamanan finansial hanya memberikan perlindungan terbatas terhadap perkawinan anak.

Sasaran untuk mengakhiri segala bentuk diskriminasi terhadap perempuan antara lain diukur dengan meningkatnya jumlah undang-undang / kebijakan tentang kesetaraan gender dan pemberdayaan perempuan. Pancasila sebagai Ideologi Negara (terutama prinsip "Kemanusiaan yang Adil dan Beradab") menjamin persamaan hak dan perlakuan non-diskriminatif bagi lakilaki dan perempuan. Selain itu, Undang-Undang Dasar Negara Republik Indonesia Tahun 1945 (Pasal 27, 28, dan 31) sebagai Perintah Pokok dan Landasan Konstitusi memberikan kepastian hukum atas perlakuan yang adil dan setara. Indonesia juga telah meratifikasi Convention on the Elimination of all forms of Discrimination Against Women (CEDAW) yang diterjemahkan menjadi Undang-Undang Nomor 7 Tahun 1984 tentang Ratifikasi Konvensi Penghapusan Segala Bentuk Diskriminasi terhadap Perempuan. Indonesia telah berkomitmen untuk menghapus segala bentuk diskriminasi terhadap perempuan dalam berbagai upaya dan meningkatkan kesetaraan gender yang berkelanjutan. Apalagi, pasca pencanangan Beijing Platform for Action (1995) tentang strategi pemberdayaan perempuan dan kesetaraan gender dalam pembangunan, Indonesia mengeluarkan Instruksi Presiden (Inpres) Nomor 9 Tahun 2000 tentang Pengarusutamaan Gender (Pengarusutamaan Gender / PUG) dalam pembangunan nasional. Dasar hukum ini menginstruksikan seluruh kementerian / lembaga dan pemerintah daerah untuk melaksanakan kesetaraan gender. Adapun kebijakan / undang-undang penting lainnya terkait dengan penghapusan segala bentuk diskriminasi terhadap perempuan di Indonesia, antara lain:

1. Undang-Undang Nomor 39 Tahun 1999 tentang Hak Asasi Manusia.

2. Undang-Undang Nomor 23 Tahun 2004 tentang Penghapusan Kekerasan Dalam Rumah Tangga. Undang-undang ini merupakan salah satu instrumen hukum untuk menghapus diskriminasi terhadap wanita dalam pernikahan dan rumah tangga.

3. Undang-Undang Nomor 12 Tahun 2006 tentang Kebangsaan.

17 Indonesia UNFPA, Pencegahan \& Penanganan Kekerasan Berbasis Gender (KBG) Di Masa Darurat Ringkasan Temuan, 2019, hlm. 1-12. 
4. Undang-Undang Nomor 21 Tahun 2007 tentang Pemberantasan Tindak Pidana Perdagangan Manusia. Undang-undang ini merupakan salah satu komitmen negara untuk menghapus diskriminasi terhadap perempuan dalam konteks kejahatan perdagangan manusia.

5. Undang-Undang Nomor 2 Tahun 2008 tentang Partai Politik.

6. Undang-Undang Nomor 42 Tahun 2008 tentang Pemilihan Umum.

7. Undang-Undang Nomor 36 Tahun 2009 tentang Kesehatan. Pasal 136 dan 137 tentang kesehatan reproduksi mengatur tentang tanggung jawab pemerintah dalam memberikan informasi, pendidikan, dan layanan kesehatan reproduksi kepada remaja.

8. Undang-Undang Nomor 8 Tahun 2012 tentang Pemilu, yang menjamin keterlibatan perempuan dalam Pemilu dan mengatur syarat minimal $30 \%$ keterwakilan perempuan.

9. Undang-Undang Nomor 6 Tahun 2014 tentang Desa. Undangundang ini mengatur partisipasi warga (termasuk perempuan) dalam proses perencanaan, pelaksanaan, dan pemantauan pembangunan desa.

10. Undang-Undang Nomor 13 Tahun 2014, sebagai revisi dari Undang-Undang Nomor 23 Tahun 2002 tentang Perlindungan Anak.

Advokasi penghapusan perkawinan anak telah dilakukan di tingkat desa, kabupaten hingga nasional oleh berbagai organisasi dan aliansi di seluruh Indonesia. Di tingkat nasional, advokasi dilakukan oleh lembaga donor internasional, LSM, Kementerian Pemberdayaan Perempuan dan Perlindungan Anak, serta Menteri Koordinator Bidang Pembangunan Manusia dan Kebudayaan mendorong Jokowi untuk mengeluarkan Peraturan Pemerintah Pengganti Undang-Undang (Perppu). Jokowi berjanji akan mengeluarkan keputusan untuk melarang pernikahan anak pada April 2018 (Harsono 2018). Namun hingga akhir 2018, janji tersebut belum terpenuhi.

\section{SIMPULAN}

Perkawinan anak memiliki dampak negatif yang signifikan bagi perempuan dan laki-laki serta anak-anak mereka. Dampak ini termasuk tingkat pendidikan yang lebih rendah (untuk laki-laki dan perempuan), perempuan memiliki kemungkinan lebih kecil untuk bekerja, baik laki-laki maupun perempuan dipekerjakan dalam pekerjaan berpenghasilan rendah dan tinggal di rumah tangga dengan pendapatan per kapita yang tidak memadai. Pernikahan yang melibatkan seorang gadis muda yang menikah dengan pria yang lebih tua lebih cenderung berakhir dengan perceraian daripada pernikahan lainnya. Baik perempuan maupun laki-laki yang menikah pada usia dini menunjukkan bahwa keterlibatan mereka dalam pengambilan keputusan rumah tangga lebih rendah. Selain berupaya mengurangi prevalensi perkawinan anak, pemerintah dapat mengembangkan kebijakan untuk mengurangi dampak negatif perkawinan anak. Kebijakan yang membantu, alih-alih melarang, remaja yang telah menikah untuk bersekolah dapat mengurangi dampak negatif pernikahan anak terhadap pencapaian pendidikan, dan akibatnya, pendapatan.

Kebijakan yang mempromosikan informasi dan akses ke keluarga berencana untuk anak laki-laki dan perempuan cenderung mencegah kehamilan dini dan berisiko. Kebijakan yang mendorong perempuan untuk melakukan pemeriksaan antenatal dan mengakses persalinan yang memadai secara medis juga akan mengurangi dampak negatif yang terkait dengan pernikahan dini. Membantu individu yang menikah dini untuk mendapatkan akta kelahiran (dan menikah setelah mencapai usia legal) juga dapat meningkatkan kemampuan keluarga tersebut untuk mengakses pendidikan, perlindungan sosial, dan program lain yang dapat meningkatkan kesejahteraan mereka. 


\section{DAFTAR PUSTAKA}

\section{Dokumen Hukum}

Republik Indonesia, Undang-Undang Tentang Perkawinan, Nomor 1 Tahun 1974. LNRI Tahun 1974 Nomor 1, TLNRI Nomor 3019.

, Undang-Undang Tentang Perubahan Atas Undang-Undang Nomor 1 Tahun 1974 Tentang, Nomor 16 Tahun 2019. LNRI Tahun 2019 Nomor 186, TLNRI Nomor 6401.

\section{Buku:}

Muzakir, Ahmad dan Joko Sutrisno. Psikologi Pendidikan, Bandung: Pustaka Setia, 1997.

Indonesia UNFPA. "Pencegahan \& Penanganan Kekerasan Berbasis Gender (KBG) Di Masa Darurat Ringkasan Temuan," 2019, 1-12.

Koro Abdi. Perlindungan Anak Di Bawah Umur Dalam Perkawinan Usia Muda Dan Perkawinan Siri, Bandung: PT Alumni, 2012.

\section{Jurnal:}

Glick, Peter, Christopher Handy, dan David E. Sahn. "Schooling, Marriage, and Age at First Birth in Madagascar." Population Studies, 2015. https://doi.org/10.1080/00324728.2015.1053513.

International Law Making. "Dekiarasi Universal Hak-Hak Asasi Manusia." Indonesian Journal of International Law, 2006. https://doi.org/10.1017/CB09781107415324.004.

Judiasih, Sonny Dewi, Susilowati Suparto, Anita Afriana, dan Deviana Yuanitasari. "Women, Law and Policy: Child Marriage Practices in Indonesia." Notariil: Jurnal Kenotariatan, 2018. https://doi.org/10.22225/jn.3.1.647.47-55.

Kohno, Ayako, Teeranee Techasrivichien, S. Pilar Suguimoto, Maznah Dahlui, Nik Daliana Nik Farid, dan Takeo Nakayama. "Investigation of the Key Factors That Influence the Girls to Enter into Child Marriage: A Meta-Synthesis of Qualitative Evidence." PLoS ONE, 2020. https://doi.org/10.1371/journal.pone.0235959.

Lee-Rife, Susan, Anju Malhotra, Ann Warner, dan Allison Mcgonagle Glinski. "What Works to Prevent Child Marriage: A Review of the Evidence." Studies in Family Planning, 2012. https://doi.org/10.1111/j.1728-4465.2012.00327.x.

MAMPU. “Consequences of Child Marriage in Indonesia," 2020, 1-60.

McCleary-Sills, Jennifer, Lucia Hanmer, Jennifer Parsons, dan Jeni Klugman. “Child Marriage: A Critical Barrier to Girls' Schooling and Gender Equality in Education." Review of Faith and International Affairs, 2015. https://doi.org/10.1080/15570274.2015.1075755. 
Muhajarah, Kurnia. "Kekerasan Terhadap Perempuan Dalam Rumah Tangga: Perspektif Sosio-Budaya, Hukum, Dan Agama." Sawwa: Jurnal Studi Gender, 2017. https://doi.org/10.21580/sa.v11i2.1452.

Murni, Sri. "The Marriage Age Limit According to Indonesian Law No. 16, 2019 as Effort to Child Protection" 140, no. 16 (2020): 222-30. https://doi.org/10.2991/aebmr.k.200513.047.

Paul, Pintu. "Effects of Education and Poverty on the Prevalence of Girl Child Marriage in India: A District-Level Analysis." Children and Youth Services Review, 2019. https://doi.org/10.1016/j.childyouth.2019.02.033.

Rumble, Lauren, Amber Peterman, Nadira Irdiana, Margaret Triyana, and Emilie Minnick. "An Empirical Exploration of Female Child Marriage Determinants in Indonesia." BMC Public $\quad$ Health, 2018. https://doi.org/10.1186/s12889-018-5313-0.

Sabri, Bushra, Andrea L. Wirtz, Joseph Ssekasanvu, Bareng A.S. Nonyane, Fred Nalugoda, Joseph Kagaayi, Robert Ssekubugu, dan Jennifer A. Wagman. "Intimate Partner Violence, HIV and Sexually Transmitted Infections in Fishing, Trading and Agrarian Communities in Rakai, Uganda." BMC Public Health, 2019. https://doi.org/10.1186/s12889-019-6909-8.

Susanti, Emy. "Unequal Gender Relations in the Practices of Girl Marriage in Poor Families at East Java Province." Masyarakat, Kebudayaan Dan Politik, 2019. https://doi.org/10.20473/mkp.v31i42018.440-450.

World Health Statistic. "Monitoring Health for the SDGs." World Health Statistic, 2019. https://doi.org/10.1007/978-1-349-04787-1_12. 